\title{
ANALISIS RISIKO PORTOFOLIO DENGAN MENGGUNAKAN METODE SIMULASI MONTE CARLO (STUDI PADA PERUSAHAAN YANG TERDAFTAR INDEKS LQ45 DI BURSA EFEK INDONESIA PERIODE 2015-2018)
}

\author{
Indria Astuti $^{1}$, Burhanudin ${ }^{2}$, Baiq Nurul Suryawati ${ }^{3}$ \\ ${ }^{1}$ Mahasiswa di Fakultas Ekonomi dan Bisnis Universitas Mataram,indriaastuti2@gmail.com \\ ${ }^{2}$ Dosen di Fakultas Ekonomi dan Bisnis Universitas Mataram, burhanudin mtr@yahoo.com \\ ${ }^{3}$ Dosen di Fakultas Ekonomi dan Bisnis Universitas Mataram, nurul.suryawati@unram.ac.id
}

\begin{abstract}
ABSTRAK
Dalam penulisan ini akan dilakukan pembahasan mengenai analisis risiko portofolio dengan metode Simulasi Monte Carlo menggunakan penghitungan Value at Risk $(\mathrm{VaR})$ sebagai estimasi maksimal kerugian dalam portofolio tersebut. Penggunaan Simulasi Monte Carlo untuk menganalisis risiko portofolio dilakukan agar risiko dapat diukur dengan lebih akurat berdasarkan pembangkit nilai acak yang dihasilkan oleh pengulangan sebanyak 1000 iteration, yang didesain untuk menggambarkan risiko dari suatu aset tertentu.

Portofolio merupakan gabungan dari dua atau lebih saham individual. Dalam penghitungan analisis risiko portofolio, hal yang perlu dilakukan terlebih dahulu adalah pembentukan portofolio terlebih dahulu. Pembentukan portofolio dalam penelitian ini menggunakan metode Single Index Model. Data yang digunakan dalam penelitian ini data saham indeks LQ45 periode 2015 sampai 2018. Pemilihan saham kategori LQ45 karena liquiditas saham yang tergolong LQ45 sangat liquid dan banyak peminat di pasar saham.

Berdasarkan hasil perhitungan, menunjukkan bahwa saham-saham yang membentuk portofolio optimal diantaranya pada semester 1 terdapat 4 saham yaitu: GGRM, BMTR, SILO, ASRI. Pada semester 2 terdapat 1 saham yang membentuk portofolio optimal yaitu saham ITMG. Pada semester 3 terdapat 4 saham, yaitu: JSMR, GGRM, SCMA, dan TBIG. Pada semester 4 terdapat 7 saham, yaitu: INTP, MPPA, WIKA, PGAS, PWON, PTPP dan AALI. Pada semester 5 terdapat 9 saham, yaitu: ELSA, LPKR, PPRO, AALI, PTPP, ASRI, ADRO, AKRA dan ANTM. Pada semester 6 terdapat 2 saham, yaitu SSMS dan AALI. Pada semester 7 terdapat 7 saham, yaitu: SRIL, BSDE, TLKM, BRPT, SSMS, TPIA, dan LPPF. Pada semester 8 terdapat 6 saham, yaitu: SMRA, ANTM, PTPP, TLKM, SMGR, dan SRIL. Kemudian nilai VaR portofolio saham LQ45 diperoleh sebesar 0,04534961 yang berarti menunjukkan kerugian yang akan diderita oleh investor tidak akan melebihi $\mathrm{Rp} 45.349 .610$ jika investasi awal sebesar $\mathrm{Rp}$ 1.000.000.000.
\end{abstract}

Kata kunci: Portofolio, Single Index Model, Simulasi Monte Carlo, VaR

\section{ABSTRACT}

In this paper a discussion on portfolio risk analysis will be conductedmethod Monte Carlo Simulation usingusing calculation of Value at Risk (VaR) as the maximum estimate of losses in the portfolio. The use of Monte Carlo Simulation to analyze portfolio risk is done so that risk can be measured more accurately based on random value generator generated by repetition of 1000 iterations, which are designed to describe the risk of a particular asset.

A portfolio is a combination of two or more individual shares. In calculating portfolio risk analysis, what needs to be done first is portfolio formation first. The formation of portfolios in this study uses themethod Single Index Model. The data used in this study are stock data for the LQ45 index for the period of 2015 to 2018. The selection of shares in the LQ45 category is because the liquidity of stocks classified as LQ45 is very liquid and many interested in the stock market.

Based on the results of calculations, it shows that stocks that make up an optimal portfolio include in the first semester there are 4 stocks, namely: GGRM, BMTR, SILO, ASRI. In semester 2 there is 1 share that forms the optimal portfolio, namely ITMG shares. In semester 3 there are 4 shares, namely: JSMR, GGRM, SCMA, and TBIG. In semester 4 there are 7 shares, namely: INTP, MPPA, WIKA, PGAS, 
PWON, PTPP and AALI. In semester 5 there are 9 stocks, namely: ELSA, LPKR, PPRO, AALI, PTPP, ASRI, ADRO, AKRA and ANTM. In semester 6 there are 2 shares, namely SSMS and AALI. In the 7th semester there were 7 stocks, namely: SRIL, BSDE, TLKM, BRPT, SSMS, TPIA, and LPPF. In the 8th semester there were 6 stocks, namely: SMRA, ANTM, PTPP, TLKM, SMGR, and SRIL. Then the LQ45 stock portfolio VaR value is obtained at 0.04534961, which means that the loss to be suffered by investors will not exceed Rp. 45,349,610 if the initial investment is Rp. 1,000,000,000.

Key words: Portfolio, Single Index Model, Monte Carlo Simulation, VaR

\section{Latar Belakang}

\section{PENDAHULUAN}

Investasi adalah komitmen saat ini atas uang atau sumber daya lain dengan harapan untuk mendapatkan keuntungan di masa depan. Halim (2005:5) menyatakan bahwa pada umumnya, investasi dapat dikategorikan menjadi dua jenis yaitu investasi pada aset-aset riil (real assets) dan pada aset-aset finansial (financial assets). Investasi aset riil adalah investasi yang dilakukan pada aktiva yang bisa terlihat dan dapat diukur secara jelas misalnya investasi dengan membeli tanah, rumah, emas dan sebagainya. Investasi aset finansial adalah jenis investasi yang dapat dilakukan dengan membeli aktiva keuangan yang dapat diperjual-belikan di pasar uang (money market), pasar modal (capital market), atau pasar turunan (derivative market). Adapun instrument pasar uang sendiri antara lain interbank call money, sertifikat bank Indonesia (SBI) / treasury bills, sertifikat deposito, surat berharga pasar uang, banker's acceptance, commercial paper, dan repurchase agreement. Kemudian pada pasar modal instrument yang diperjual belikan terdiri dari saham dan obligasi. Terakhir pada pasar turunan terdapat opsi, warrant, dan future contract sebagai pilihan untuk berinvestasi.

Saham (stock) merupakan salah satu instrumen pasar keuangan yang paling populer. Saham dikenal instrument investasi yang banyak dipilih para investor karena saham mampu memberikan tingkat keuntungan yang menarik. Saham dapat didefinisikan sebagai tanda penyertaan modal seseorang atau pihak (badan usaha) dalam suatu perusahaan atau perseroan terbatas. Dengan menyertakan modal tersebut, maka pihak tersebut memiliki klaim atas pendapatan perusahaan, klaim atas asset perusahaan, dan berhak hadir dalam Rapat Umum Pemegang Saham.

Salah satu tempat berinvestasi di Indonesia adalah pasar modal, pasar modal di Indonesia bernama Bursa Efek Indonesia (BEI) atau Indonesia Stock Exchange (IDX). Setiap investor atau calon investor yang mempunyai dana berlebih yang ingin menginvestasikan dananya di Bursa Efek Indonesia akan melihat Indeks LQ45 karena Indeks LQ45 sebagian acuan para investor untuk berinvestasi. Indeks LQ 45 adalah nilai kapitalisasi pasar dari 45 saham yang paling likuid dan memiliki frekuensi perdagangan yang tinggi sehingga para investor tertarik menanamkan dananya di indeks LQ45. Berikut ini tabel perkembangan rata-rata harga saham Indeks LQ45 di Bursa Efek Indonesia.

Tabel 1. Perkembangan Rata-Rata Harga Saham Pada Indeks LQ45 Bursa Efek Indonesia Tahun 2015-2018

\begin{tabular}{|c|c|c|}
\hline Tahun & Harga Saham & Perkembangan \\
\hline 2015 & 828,88 & - \\
\hline 2016 & 866,44 & $4,53 \%$ \\
\hline 2017 & 963,52 & $11,20 \%$ \\
\hline 2018 & 995,23 & $3,29 \%$ \\
\hline
\end{tabular}

Sumber: data dari www.idx.co.id 
Tabel diatas menunjukkan bahwa harga saham pada Indeks LQ45 selalu mengalami peningkatan dari tahun ke tahun. Tahun 2016 rata-rata harga saham mengalami peningkatan sebesar 4,53\% dari tahun 2015. Kemudian tahun 2017 mengalami peningkatan yang signifikan sebesar $11,20 \%$ dari tahun 2016. Dan pada tahun 2018 rata-rata harga saham mengalami peningkatkan sebesar 3,29\% dari tahun sebelumnya.

Dalam berinvestasi pada saham ada dua faktor yang paling dipertimbangkan oleh investor, yaitu tingkat pengembalian (return) dan risiko (risk). Dua faktor ini merupakan hal yang berlawanan, dalam arti invertor menyukai return yang tinggi dan tidak begitu menyukai risiko yang tinggi. Pada kenyataan terdapat hubungan yang alami antara besarnya pengembalian dan besarnya risiko, karena semakin besar pengembalian yang diharapkan maka akan semakin besar pula risiko yang akan dihadapi atau tingkat pengembalian yang tinggi akan selalu diikuti dengan tingkat risiko yang tinggi pula.

Risiko investasi secara umum dibedakan menjadi dua, yaitu risiko sistematis (systematic risk) dan risiko tidak sistematis (unsystematic risk). Risiko sistematis yaitu risiko yang tidak dapat dihindari karena risiko ini dipengaruhi oleh faktor-faktor makro yang dapat mempengaruhi pasar secara keseluruhan seperti keadaan ekonomi dan politik. Sedangkan risiko tidak sistematis yaitu risiko investasi yang dapat dihindari melalui diversifikasi, karena risiko ini hanya ada dalam satu perusahaan atau industri tertentu. Diversifikasi investasi saham dapat dilakukan dengan membentuk portofolio saham.

Menurut Sunariyah (2003:178) portofolio diartikan sebagai serangkaian kombinasi aktiva yang diinvestasikan dan dipegang oleh pemodal, baik perorangan maupun lembaga. Untuk membentuk portofolio yang optimal, investor harus menentukan portofolio yang efisien terlebih dahulu. Portofolio efisien adalah portofolio yang menghasilkan tingkat return maksimal dengan risiko tertentu, atau tingkat return tertentu dengan risiko minimal. Portofolio optimal merupakan portofolio yang dipilih seseorang investor dari sekian banyak pilihan yang ada pada kumpulan portofolio yang efisien (Tandelilin, 2001:47).

Dalam pembentukan portofolio optimal dapat menggunakan pendekatan Single Index Model. Pendekatan Markowitz dikemukakan pertama kali oleh Markowitz pada tahun 1952. Markowitz didasarkan atas pendekatan mean (rata-rata) dan variance (varian), dimana mean merupakan pengukuran tingkat return dan varian merupakan pengukuran tingkat risiko. Pendekatan Single Index Model memberikan analisis varian yang lebih mudah jika dibandingkan dengan Markowitz. Single Index Model menjelaskan hubungan antara return dari setiap sekuritas individual dengan return indeks pasar. Model ini memberikan alternatif untuk menghitung varian dari suatu portofolio, yang lebih sederhana dan mudah dihitung jika dibandingkan dengan metode perhitungan Markowitz.

Pengukuran risiko merupakan aspek yang sangat penting dalam analisis keuangan yang berkaitan dengan investasi dana yang besar, hal ini berkaitan dengan besarnya dana yang diinvestasikan dan hal yang paling utama diperhatikan setiap calon investor adalah menentukan asset beresiko mana yang akan dibeli. Selain dengan menggunakan varian dalam menentukan risiko suatu portofolio juga dapat menggunakan Value at Risk (VaR). Menurut Jorion (2007) VaR merupakan salah satu alat analisis untuk mengukur risiko disamping notional amount, sensivity measures, dan scenario. Untuk notional amount hanya dapat memberikan indikasi dari potensi kerugian yang mungkin terjadi. Walaupun sensivity measures dapat memberikan informasi terkait dengan sensitivitas dari surat berharga atau bunga namun tidak mampu mengukur perubahan yang mendatangkan kerugian dan juga mengabaikan hubungan 
hubungan yang tidak segaris antara harga dan keuntungan. Sedangkan scenario mampu untuk menggambarkan hubungan nonlinier dan juga pengaruh yang ektreme terhadap harga namun tidak dapat menghubungkannya dengan potensi kerugian yang mungkin terjadi. Disamping ia tidak mampu menghubungkan atau menggabungkan risiko yang mungkin terjadi antar berbagai pasar. Namun kesemua kendala dalam alat ukur diatas dapat dilakukan atau diukur dengan menggunakan Value at Risk (VaR).

Menurut Jorion (2007) saat ini Value at Risk secara luas telah menjadi alat pengukuran risiko. VaR dapat menjawab seberapa besar kerugian investor dapat terjadi dengan probabilitas X \% dalam waktu yang telah ditentukan. VaR mengukur jumlah risiko maksimum yang akan mereka terima. Ada tiga metode utama untuk menghitung VaR yaitu metode parametric (disebut juga metode varians-kovarians), metode simulasi historis dan metode simulasi monte carlo. Ketiga metode mempunyai karakteristik dengan kelebihan dan kekurangannya masing-masing. Metode monte carlo merupakan metode yang paling kuat untuk mengukur VaR karena simulasi monte carlo melakukan percobaan berulang kali dengan pembangkitan bilangan acak sehingga didapatkan nilai random pada probabilitas frekuensi tertentu, yang nantinya akan digunakan sebagai estimasi untuk memprediksi kondisi pergerakan saham di masa mendatang.

Adapun penelitian ini bertujuan untuk melengkapi rangkaian penelitian sebelumnya. Berdasarkan penelitian terdahulu mengenai analisis risiko portofolio menggunakan metode simulasi monte carlo pada beberapa objek penelitian menunjukkan hasil kerugian. Sehingga pada penelitian ini akan menduplikasi hal serupa untuk mengetahui apakah jika dihitung pada Indeks LQ45 juga mengalami kerugian. Hal inilah yang menjadi dasar untuk dilakukannya penelitian dengan judul "Analisis Risiko Portofolio Dengan Menggunakan Metode Simulasi Monte Carlo (Studi pada Perusahaan yang Terdaftar Indeks LQ45 di Bursa Efek Indonesia Periode 20152018)"

\section{Rumusan Masalah}

Berdasarkan latar belakang tersebut, maka yang menjadi rumusan masalah dalam penelitian ini adalah bagaimana menganalisis risiko portofolio menggunakan perhitungan Value at Risk dengan metode simulasi Monte Carlo pada saham-saham indeks LQ45 periode 2015-2018 di Bursa Efek Indonesia?

\section{Investasi}

\section{KAJIAN PUSTAKA}

Investasi adalah penempatan sejumlah dana yang dilakukan pada saat sekarang untuk memperoleh keuntungan di masa datang. Menurut Susilo (2009:2) investasi dibedakan menjadi dua, yaitu investasi pada aset nyata (real asset) dan investasi pada aset finansial (financial asset). Investasi pada aset nyata contohnya seperti pembelian emas, tanah, properti atau mendirikan perusahaan. Sedangkan investasi pada aset finansial adalah dengan membeli instrumen keuangan, misalnya saham, obligasi, waran, right issue. Instrumen ini bukan berupa aset nyata melainkan hanya berupa kertas klaim (bukti) terhadap penerbitnya. Hartono (2016:7) mengklasifikasikan aktivitas investasi ke dalam aktiva keuangan menjadi dua tipe:

1. Investasi Langsung

Investasi langsung dapat dilakukan dengan membeli aktiva keuangan yang dapat diperjual-belikan di pasar uang (money market), pasar modal (capital market), atau pasar turunan (derivative market). Aktiva keuangan yang dapat diperjual-belikan di pasar uang (money market) berupa aktiva yang mempunyai tingkat risiko kecil, 
jatuh tempo yang pendek dengan tingkat likuiditas yang tinggi. Aktiva keuangan yang diperjual-belikan di pasar modal memiliki sifat investasi jangka panjang berupa saham-saham (equity securities) dan surat- surat berharga pendapatan tetap (fixed income securities). Opsi (option) dan futures contract merupakan surat-surat berharga yang diperdagangkan di pasar turunan (derivative market). Investasi langsung tidak hanya dilakukan dengan membeli aktiva keuangan yang dapat diperjual-belikan, namun juga dapat dilakukan dengan membeli aktiva keuangan yang tidak dapat diperjual-belikan seperti: tabungan, giro, dan sertifikat deposito.

2. Investasi Tidak Langsung

Investasi tidak langsung dilakukan dengan membeli surat-surat berharga di perusahaan investasi. Perusahaan investasi adalah perusahaan yang menyediakan jasa-jasa keuangan dengan cara menjual sahamnya ke publik. Investasi melalui perusahaan investasi menawarkan keuntungan tersendiri bagi investor. Hanya dengan modal yang relatif kecil, investor dapat mengambil keuntungan karena pembentukan portofolio investasinya. Selain itu, dengan membeli saham perusahaan investasi, investor tidak membutuhkan pengetahuan dan pengalaman yang tinggi. Dengan pembelian tersebut investor dapat membentuk portofolio yang optimal.

\section{Return dan Risiko Investasi}

Dua unsur yang melekat pada setiap modal atau dana yang diinvestasikan adalah hasil (return) dan risiko (risk). Return merupakan hasil yang diperoleh dari investasi sesuai dengan tujuan investasi yang dilakukan investor tidak lain bertujuan untuk memaksimalkan keuntungan (return).

Tingkat pengembalian (return) biasanya di bedakan menjadi dua yaitu: return realisasi (realized return) dan return ekspektasi (expected return). Return ekspektasi adalah return yang diharapkan akan diperoleh oleh investor di masa yang akan datang. Return realisasi merupakan return yang telah terjadi, dihitung berdasarkan data historis.

Adapun pengertian risiko yang dijabarkan oleh Tandelilin (2001:47) adalah: risiko merupakan kemungkinan perbedaan antara return yang aktual dengan return yang diharapkan. Semakin besar kemungkinan perbedaannya, berarti semakin besar risiko investasi tersebut. Begitu juga dengan pendapat Halim (2005:42) mengenai pengertian risiko, yaitu: risiko merupakan besarnya penyimpangan antara tingkat pengembalian yang diharapkan (expected return) dengan tingkat pengembalian aktual (actual return).

Berdasarkan pendapat di atas maka dapat disimpulkan bahwa risiko adalah kemungkinan dari investasi yang dilakukan investor mengalami kegagalan dalam memenuhi tingkat pengembalian investor yang diharapkan. Menurut Halim (2005:51) jenis-jenis risiko investasi adalah:

1) Risiko sistematis (systematic risk)

Merupakan risiko yang tidak dapat dihilangkan dengan melakukan diversifikasi, karena fluktuasi risiko ini dipengaruhi oleh faktor-faktor makro yang dapat mempengaruhi pasar secara keseluruhan. Risiko ini disebabkan oleh faktor-faktor serentak yang mempengaruhi harga saham di pasar modal, misalnya perubahan dalam kondisi perekonomian, iklim politik, peraturan perpajakan, kebijakan pemerintah dan lain sebaginya.

2) Risiko tidak sistematis (unsystematic risk)

Merupakan risiko yang dapat dihilangkan dengan melakukan diversifikasi, karena risiko ini hanya ada dalam satu perusahaan atau industri tertentu, misalnya faktor stuktur modal, stuktur aset, tingkat likuiditas, tingkat keuntungan dan lain sebagainya. Diversifikasi risiko ini sangat penting untuk investor, karena dapat meminimumkan risiko tanpa harus mengurangi return yang diterima. 


\section{Saham}

Saham merupakan salah satu dari beberapa alternatif yang dapat dipilih untuk berinvestasi. Investasi dengan membeli saham suatu perusahaan berarti investor telah menginvestasikan dana dengan harapan akan mendapatkan keuntungan dari hasil penjualan kembali saham tersebut.

Saham merupakan tanda bukti memiliki perusahaan yang pemiliknya disebut juga sebagai pemegang saham (shareholder atau stockholder). Bukti bahwa seseorang atau suatu pihak dapat dianggap sebagai pemegang saham adalah apabila mereka sudah tercatat sebagai pemegang saham dalam buku yang disebut Daftar Pemegang Saham (DPS). Pada umumnya DPS disajikan beberapa hari sebelum Rapat Umum Pemegang Saham diselenggarakan dan setiap pihak dapat melihat DPS tersebut. Bukti bahwa seseorang adalah pemegang saham juga dapat dilihat pada halaman belakang lembar saham, apakah namanya sudah diregistrasi oleh perusahaan (emiten) atau belum.

Harga saham bisa naik, tetapi juga bisa turun. Hal tersebut merupakan risiko investasi pada saham. Agar investasinya tidak salah, maka investor perlu melakukan penilaian terlebih dahulu terhadap saham-saham yang akan dipilihnya, untuk selanjutnya menentukan apakah saham tersebut akan memberikan tingkat keuntungan (return) yang sesuai dengan tingkat return yang diharapkan (Indarto, 2014:4.2). Penilaian saham tersebut dapat dilakukan dengan membentuk portofolio saham. Portofolio saham dapat dikelompokkan menjadi portofolio efisien dan portofolio optimal.

\section{Portofolio}

Portofolio merupakan kombinasi atau gabungan atau sekumpulan aset, baik berupa aset riil maupun aset finansial yang dimiliki oleh investor. Hakikat pembentukan portofolio adalah untuk mengurangi risiko dengan cara diversifikasi, yaitu mengalokasikan sejumlah dana investor pada berbagai alternatif investasi yang berkorelasi negatif agar dana yang dikeluarkan oleh investor dapat menghasilkan pengembalian yang optimal. Dalam teori portofolio adalah bagaimana melakukan pemilihan portofolio dari sekian banyak aset, untuk memaksimalkan return yang diharapkan pada tingkat risiko tertentu yang bersedia ditanggung investor.

\section{Return dan Risiko Portofolio}

Dalam penilaian portofolio ada dua hal yang harus dipertimbangkan sebelum investor mengambil keputusan investasi yaitu: expected return (tingkat keuntungan yang diharapkan) dan risk (risiko). Untuk menghitung tingkat keuntungan (return) yang diharapkan dan risiko (risk) suatu portofolio berarti menghitung return dan risiko suatu kumpulan asset individual yang dikombinasikan dalam suatu portofolio (membentuk portofolio). Seperti yang diketahui bahwa return investor terdiri dari dua yaitu return realisasi dan return ekspektasi (return yang diharapkan). Menurut Hartono (2016:311) return suatu portofolio juga terdiri dari 2 yaitu return realisasi portofolio (portofolio realized return) dan return ekspektasi portofolio (portofolio expected return). Return realisasi portofolio merupakan rata-rata tertimbang dari return-return realisasi tiap-tiap sekuritas tunggal. Return ekspektasi portofolio merupakan rata-rata tertimbang dari return ekspektasi masing-masing sekuritas tunggal di dalam portofolio. Begitupun untuk menghitung risiko portofolio haruslah dihitung risiko masing-masing sekuritas maupun beberapa sekuritas yang membentuk portofolio tersebut. 


\section{Portofolio efisien dan optimal}

Konsep dasar yang perlu diketahui sebagai dasar untuk memahami pembentukan portofolio optimal yaitu:

1. Portofolio Efisien

Untuk membentuk portofolio yang optimal, investor harus menentukan portofolio yang efisien terlebih dahulu. Portofolio-portofolio efisien berada di efficient set. Menurut Hartono (2016:337) portofolio yang efisien (efficient portfolio) didefinisikan sebagai portofolio yang memberikan return ekspektasi terbesar dengan risiko yang sudah tertentu atau memberikan resiko yang terkecil dengan return ekspektasi yang sudah tertentu. Sedangkan menurut Sharpe (1963), portofolio dikategorikan efisien apabila memiliki tingkat risiko yang sama, mampu memberikan tingkat keuntungan yang lebih tinggi, atau mampu menghasilkan tingkat keuntungan yang sama, tetapi dengan risiko yang lebih rendah.

2. Portofolio Optimal

Portofolio efisien belum tentu portofolio optimal. Portofolio efisien hanya mempunyai satu faktor yang baik, yaitu faktor return ekspektasian saja atau faktor risikonya saja, belum terbaik keduanya. Menurut Hartono (2016:339) portofolio optimal merupakan portofolio dengan kombinasi return ekspektasi dan risiko terbaik. Sedangkan menurut Tandelilin (2001:77) portofolio optimal adalah portofolio yang dipilih seorang investor dari sekian banyak pilihan yang ada pada kumpulan portofolio efisien. Untuk menentukan portofolio optimal kita harus menghitung return saham-saham individual yang telah memenuhi kriteria untuk dijadikan portofolio optimal. Setelah itu menghitung varian dan kovarian dari saham dan pasar. Selanjutnya menghitung risiko sistematis dan tidak sistematis saham.

\section{Model Indeks Tunggal}

Berbagai metode telah diaplikasikan dalam upaya untuk menentukan portofolio yang optimal. Salah satu diantaranya adalah penggunaan metode Single Index Model. Sharpe (1963) mengembangkan model yang disebut Model Indeks Tunggal (Single Index Model). Model ini dapat digunakan untuk menyederhanakan perhitungan di model Markowitz dengan menyediakan parameter-parameter input yang dibutuhkan di dalam perhitungan perhitungan model Markowitz.

a. Konsep Model Indeks Tunggal

Menurut Hartono (2016:407) Model Indeks Tunggal didasarkan pada pengamatan bahwa harga dari suatu sekuritas berfluktuasi searah dengan indeks harga pasar. Secara khusus dapat diamati bahwa kebanyakan saham cenderung mengalami kenaikan harga jika indeks harga saham naik. Hal ini menyarankan bahwa returnreturn dari sekuritas mungkin berkorelasi karena adanya reaksi umum (common response) terhadap perubahan- perubahan nilai pasar. Dengan dasar ini, return dari suatu sekuritas dan return dari indeks pasar yang umum dapat dituliskan sebagai hubungan:

$\mathrm{R}_{\mathrm{i}}=\mathrm{a}_{\mathrm{i}}+\beta_{\mathrm{i}} \mathrm{R}_{\mathrm{m}}$

dimana:

$\mathrm{R}_{\mathrm{i}}=$ return sekuritas ke-i

$\mathrm{a}_{\mathrm{i}}=$ suatu variabel acak yang menunjukkan komponen dari return sekuritas ke-i yang independen terhadap kinerja pasar

$\beta_{\mathrm{i}}=$ beta, yaitu koefisien yang mengukur perubahan $\mathrm{R}_{\mathrm{i}}$ akibat dari perubahan $\mathrm{R}_{\mathrm{M}}$

$\mathrm{R}_{\mathrm{M}}=$ tingkat return dari indeks pasar, juga merupakan suatu variabel acak 
Variabel ai merupakan komponen return yang tidak tergantung dari return pasar. Variabel ai dapat dipecah menjadi nilai yang diekspektasi (expected value) $\alpha_{i}$ dan kesalahan residu (residual error) $e_{i}$ sebagai berikut:

$a_{\mathrm{i}}=\alpha_{\mathrm{i}}+e_{i}$

Dengan mensubsitusikan kedua persamaan diatas, maka akan didapatkan persamaan model indeks tunggal sebagai berikut:

$\mathrm{R}_{\mathrm{i}}=\alpha_{\mathrm{i}}+\beta_{\mathrm{i}} . \mathrm{R}_{\mathrm{M}}+\mathrm{e}_{\mathrm{i}}$

dimana:

$\alpha_{\mathrm{i}} \quad=$ nilai ekspektasi dari return sekuritas yang independent terhadap return pasar

$\mathrm{e}_{\mathrm{i}}=$ kesalahan residu yang merupakan variabel acak dengan nilai ekspektasinya sama dengan nol atau $\mathrm{E}\left(e_{i}\right)=0$.

\section{Value at Risk (VaR) Simulasi Monte Carlo}

Saat ini telah banyak dikembangkan dalam perhitungan nilai risiko dalam berinvestasi untuk mengurangi risiko agar para investor dapat megetahui nilai risiko lebih dini. Salah satu bentuk pengukuran nilai risiko yang sering digunakan adalah Value at Risk (VaR).

\section{a. Konsep Value at Risk (VaR)}

Pada tahun 1994, J.P. Morgan mempopulerkan konsep Value at Risk (VaR) sebagai alat ukur risiko. Menurut Jorion dalam Penza dan Bansal (2001) "VaR summarizes the expected maximum loss (or worst loss) over a target horizon within a given confidence level." (VaR merangkum kerugian maksimum yang diharapkan atau kerugian terburuk atas target horizon dengan tingkat kepercayaan tertentu). Adapun menurut Edwards (2014) "Value- at-risk is typically defined as the maximum expected loss on a financial instrument, or a portfolio of financial instruments, over a given period of time and given level of confidence." (Value at Risk secara khas dapat didefinisikan sebagai kerugian maksimum yang diharapkan pada instrumen finansial atau sebuah portofolio dari instrumem finansial, atas periode waktu tertentu dan tingkat kepercayaan tertentu.

Berdasarkan definisi di atas, dapat diketahui bahwa terdapat dua faktor utama yang digunakan untuk mendeskripsikan VaR. Pertama, pada perhitungan VaR dibutuhkan berapa lama periode waktu di mana kerugian akan terjadi. Semakin lama periode waktu yang digunakan maka nilai VaR akan semakin besar. Kedua, dalam melakukan pengukuran VaR dibutuhkan tingkat kepercayaan tertentu yang mengindikasikan kemungkinan terjadinya kerugian yang lebih tinggi nilainya dari VaR.

Pada portofolio, VaR diartikan sebagai estimasi kerugian maksimum yang akan dialami suatu portofolio pada periode waktu tertentu dengan tingkat kepercayaan tertentu. Oleh karena itu, terdapat kemungkinan bahwa suatu kerugian yang akan diderita oleh portofolio selama periode kepemilikan akan lebih rendah dibandingkan limit yang dibentuk dengan VaR.

\section{b. Keunggulan Value at Risk}

Perkembangan model VaR ini tidak terlepas dari berbagai keunggulan yang ditawarkan. Keunggulan-keunggulan VaR antara laian:

1) VaR mudah dipahami untuk mengukur risiko dari suatu portofolio karena ukuran risiko disajikan secara kuantitatif dalam bentuk bilangan berupa satuan mata uang yang dapat dengan mudah dibandingkan dengan expected return portofolio.

2) Memperhitungkan korelasi antar risiko yang berbeda serta dilengkapi dengan probabilitas atau kemungkinan terjadinya kerugian. 
3) VaR digunakan untuk mengukur risiko jangka pendek maupun jangka panjang dengan konsep yang sederhana dan fleksibel.

\section{c. Value at Risk dengan Metode Simulasi Monte Carlo}

Penggunaan metode simulasi Monte Carlo untuk mengukur risiko telah dikenalkan oleh Boyle pada tahun 1977. Pengestimasian Value at Risk (VaR) dengan metode simulasi Monte Carlo pada dasarnya adalah melakukan simulasi dengan membangkitkan bilangan acak berdasarkan karakteristik dari data yang akan dibangkitkan, yang kemudian digunakan untuk mengestimasi nilai VaR-nya. Dalam pengukuran VaR dengan metode simulasi Monte Carlo data harus mengikuti distribusi normal.

\section{METODE PENELITIAN}

\section{Jenis Penelitian}

Jenis penelitian ini termasuk penelitian deskriptif. Menurut Sugiyono (2017:35) penelitian deskriptif adalah penelitian yang dilakukan untuk mengetahui nilai variabel mandiri, baik satu variabel atau lebih (independen) tanpa membuat perbandingan atau menghubungkan dengan variabel lain. Dalam penelitian ini yang akan dideskripsikan adalah pembentukan portofolio optimal saham yang terdaftar pada indeks LQ-45 menggunakan single index model serta mengukur value at risk portofolio menggunakan metode simulasi monte carlo.

\section{Lokasi dan Waktu Penelitian}

Lokasi penelitian ini dilakukan di Bursa Efek Indonesia yang berada di Jakarta dengan alamat Jalan Jendral Sudirman Kav 52-53 Jakarta Selatan 12190, Indonesia. Penelitian ini dilakukan dengan mengakses data melalui internet, tidak berkunjung langsung ke lokasi. Adapun situs yang digunakan dalam mengakses yaitu www.idx.co.id dan www.sahamok.com. Waktu penelitian berlangsung pada periode 2015 sampai 2018.

\section{Populasi Penelitian}

Sugiyono (2017:115) menyatakan bahwa populasi adalah wilayah generalisasi terdiri atas obyek atau subyek yang mempunyai kualitas dan karakteristik tertentu dan ditetapkan oleh peneliti untuk dipelajari dan kemudian ditarik kesimpulan. Dalam penelitian ini yang menjadi populasi adalah saham perusahaan yang masuk pada indeks LQ-45 periode 2015 sampai 2018.

\section{Sumber Data}

Sumber data dalam penelitian ini adalah data sekunder, yaitu data yang sudah diolah pihak lain serta melalui studi pustaka yang ada hubungannya dengan masalah yang dihadapi dan dianalisis, disajikan dalam bentuk informasi. Pihak lain yang dimaksud mengolah data pada penelitian dalam hal ini adalah Bursa Efek Indonesia. Data sekunder diperoleh dari website Bursa Efek Indonesia yaitu www.idx.co.id

\section{Prosedur Analisis Data}

1. Mendeskripsikan perkembangan harga saham indeks LQ45, IHSG, dan BI rate periode 2015 sampai 2018.

2. Menghitung return realisasi dan return ekspektasi untuk masing-masing saham.

Menurut Hartono (2016:265) rumus yang digunakan untuk menentukan return dan risiko msing-masing sekuritas adalah:

$$
\begin{aligned}
& \text { Rumus return realisasi } \\
& \qquad \mathrm{Ri}=\frac{\mathrm{Pt}-\mathrm{P}(\mathrm{t}-1)}{\mathrm{P}(\mathrm{t}-1)}+\frac{\mathrm{Dt}}{\mathrm{P}(\mathrm{t}-1)}
\end{aligned}
$$


Keterangan :

$\mathrm{Ri}=$ Keuntungan (return) realisasi

$\mathrm{Pt}=$ Harga investasi sekarang

Pt-1 = Harga investasi masa lalu

Dt $=$ Deviden periode sekarang

Tingkat keuntungan yang diharapkan atau expected return tiap saham individual merupakan prosentase rata-rata realized return saham i dibagi jumlah realized return saham i. Dihitung dengan program Excel menggunakan rumus Average atau menggunakan rumus:

$\mathrm{E}(\mathrm{Ri})=\frac{\sum_{j-1}^{n} R i j}{n}$

Keterangan:

$\mathrm{E}(\mathrm{Ri})=$ Expected return pada periode $\mathrm{i}$

Rij $\quad=$ Keuntungan (return) investasi $\mathrm{i}$

$\mathrm{n} \quad=$ Periode pengamatan

Menghitung return pasar dan return ekspektasi pasar

$\mathrm{R}_{\mathrm{M}}=\frac{I H S G_{t}-I H S G_{t-1}}{I H S G_{t-1}}, \mathrm{E}\left(\mathrm{R}_{\mathrm{M}}\right)=\frac{\sum_{i=1}^{N} R_{M}}{n}$

Keterangan:

$\mathrm{R}_{\mathrm{M}} \quad=$ Return pasar

$\mathrm{IHSG}_{\mathrm{t}}=$ Indeks harga saham gabungan periode sekarang

$\mathrm{IHSG}_{\mathrm{t}-1}=$ Indeks harga saham gabungan periode yang lalu

$\mathrm{E}(\mathrm{RM}) \quad=$ Return ekspektasi pasar

$\mathrm{n} \quad=$ Periode pengamatan

Menghitung standar deviasi saham dan pasar

Standar deviasi digunakan untuk mengukur risiko dari realized return, yang dapat dihitung dengan program Excel menggunakan rumus STDEV atau menggunakan rumus:

$\sigma \mathrm{i}=\sqrt{\frac{\sum_{t=1}^{n}[(R i-E(R i))]^{2}}{n}}, \sigma \mathrm{M}^{2}=\frac{\sum_{i=1}^{N}\left[\left(R_{M}-E\left(R_{M}\right)\right]^{2}\right.}{n-1}$

Keterangan :

бi $\quad=$ Deviasi standar saham $\mathrm{i}$

$\sigma \mathrm{M}^{2}=$ Deviasi standar dari return pasar

$\mathrm{R}_{\mathrm{i}} \quad=$ Return saham $\mathrm{i}$

$\mathrm{R}_{\mathrm{M}} \quad=$ Return pasar

$\mathrm{E}\left(\mathrm{R}_{\mathrm{i}}\right) \quad=$ Return ekspektasi saham $\mathrm{i}$

$\mathrm{E}\left(\mathrm{R}_{\mathrm{M}}\right) \quad=$ Return ekspektasi pasar

$\mathrm{n} \quad=$ Periode pengamatan

Menghitung beta masing-masing saham.

Beta $\left(\beta_{\mathrm{i}}\right)$ adalah risiko unik dari saham individual, menghitung keserongan (slope) realized return suatu saham dengan realized return pasar (IHSG) dalam periode tertentu. Beta digunakan untuk menghitung Excess Return to Beta (ERB) 
dan $\mathrm{B}_{\mathrm{j}}$ yang diperlukan untuk menghitung Cut-Off Point $\left(\mathrm{C}_{\mathrm{i}}\right)$. Beta dapat dihitung dengan program Excel menggunakan rumus Slope.

Keterangan:

$$
\beta \mathrm{i}=\frac{\sigma \mathrm{i}}{\sigma \mathrm{m} 2}
$$

$\beta_{\mathrm{i}} \quad=$ beta saham $\mathrm{i}$

$\sigma_{i}=$ standar deviasi saham $\mathrm{i}$

$\sigma_{\mathrm{m}}^{2}=$ standar deviasi pasar

Menghitung alpha masing-masing saham.

Alpha $\left(\alpha_{\mathrm{i}}\right)$ merupakan intercept realized return saham i dengan realized return pasar (IHSG), membandingkan perhitungan realized return saham i dengan realized return pasar (IHSG) dalam periode waktu tertentu. Alpha digunakan untuk menghitung variance error ( $\left.\mathrm{e}_{\mathrm{i}}\right)$. Alpha dihitung dengan program Excel menggunakan rumus Intercept atau menggunakan rumus:

$\alpha \mathrm{i}=\mathrm{E}(\mathrm{R} \mathrm{i})-\left(\beta \mathrm{i} \cdot \mathrm{E}\left(\mathrm{R}_{\mathrm{M}}\right)\right)$

Keterangan:

$\alpha_{\mathrm{i}} \quad=$ alpha saham $\mathrm{i}$

$\beta_{\mathrm{i}}=$ beta saham $\mathrm{i}$

$\mathrm{R}_{\mathrm{m}}=$ return pasar

Menghitung varian dari kesalahan residu $\left(\sigma \mathrm{ei}^{2}\right)$

Varian dari kesalahan residu menunjukkan besarnya risiko tidak sistematik yang unik terjadi dalam perusahaan. Nilai $\alpha$ dan $\beta$ yang konstan menyebabkan nilai ekspektasi dari kesalahan residu adalah sama dengan nol. Besarnya risiko tidak sistematik yang unik $\left(\sigma \mathrm{ei}^{2}\right)$ dihitung dengan menggunakan rumus:

$\sigma \mathrm{ei}^{2}=\sigma \mathrm{i}^{2}-\left(\beta \mathrm{i}^{2} . \sigma \mathrm{m}^{2}\right)$

\section{Pembentukan portofolio optimal}

Pembentukan portofolio optimal dilakukan menggunakan single index model, sedangkan perhitungannya menggunakan program microsoft excel. Berdasarkan Hartono (2016:429) Tahap pembentukan portofolio optimal menggunakan single index model adalah sebagai berikut :

A. Menghitung Excess Return to Beta (ERB)

$\mathrm{ERBi}=\frac{E(R i)-R_{B R}}{\beta i}$

Keterangan:

$\mathrm{ERBi}=$ excess return to beta sekuritas ke- $\mathrm{i}$

$\mathrm{E}(\mathrm{Ri})=$ return ekpektasi berdasarkan model indeks tunggal untuk sekuritas ke-i

$\mathrm{R}_{\mathrm{BR}}=$ return aktiva bebas risiko

$\beta \mathrm{i}=$ Beta sekuritas ke-i

B. Menghitung Cut off Point

1) Mengurutkan sekuritas-sekuritas berdasarkan nilai ERB terbesar ke nilai ERB terkecil. Sekuritas-sekuritas dengan nilai ERB terbesar merupakan kandidat untuk dimasukkan ke portofolio optimal.

2) Menghitung nilai Ai dan Bi untuk masing-masing sekuritas ke-i 


$$
\begin{gathered}
A i=\frac{\left[E(R i)-R_{B R}\right] \cdot \beta_{i}}{\sigma_{e i}^{2}} \\
\operatorname{dan}^{2} \\
B i=\frac{\beta i^{2}}{\sigma_{e i}{ }^{2}}
\end{gathered}
$$

Keterangan:

$\sigma_{\mathrm{ei}}{ }^{2}=$ varian dari kesalahan residu sekuritas ke-I yang juga merupakan risiko unik atau risiko tidak sistematis.

3) Menghitung nilai $\mathrm{Ci}$

Hitung nilai $\mathrm{Ci}$ yaitu nilai $\mathrm{C}$ untuk sekuritas ke-i yang dihitung dari kumulasi nilai-nilai $\mathrm{A}_{1}$ sampai dengan $\mathrm{Ai}$ dan nilai-nilai $\mathrm{B}_{1}$ sampai dengan

$$
C i=\frac{\sigma m^{2} \sum_{j=i}^{i} A j}{1+\sigma m^{2} \sum_{j=i}^{i} \beta j}
$$

Bi. Secara sistematis dapat ditulis dengan rumus:

Dengan mensubsitusikan niali Ai dan Bi maka rumus Ci menjadi:

$$
C i=\frac{\sigma m^{2} \sum_{j=i}^{i} \frac{\left[E(R i)-\left(R_{B R}\right)\right] \cdot \beta i}{\sigma e i^{2}}}{1+\sigma m^{2} \sum_{j=i}^{i} \frac{\beta i^{2}}{\sigma e i^{2}}}
$$

a. Besarnya cut-off point $\left(\mathrm{C}^{*}\right)$ adalah nilai $\mathrm{Ci}$ dimana nilai ERB terakhir kali masih lebih besar dari nilai $\mathrm{Ci}$

b. Sekuritas-sekuritas yang membentuk portofolio optimal adalah sekuritas-sekuritas yang mempunyai nilai ERB lebih besar atau sama dengan nilai ERB di titik $C^{*}$. Sekuritas-sekuritas yang mempunyai ERB lebih kecil dengan ERB titik $C^{*}$ tidak diikut-sertakan dalam pembentukan portofolio optimal.

4) Menentukan proporsi masing-masing sekuritas di dalam portofolio

Setelah sekuritas-sekuritas yang membentuk portofolio optimal telah dapat ditentukan, maka dilakukan perhitungan mengenai berapa porporsi masingmasing sekuritas tersebut di dalam portofolio optimal dengan rumus:

$$
W i=\frac{Z i}{\sum_{j=I}^{K} Z j}
$$

dengan nilai $Z_{\mathrm{i}}$ adalah sebesar

$$
Z i=\frac{\beta i}{\sigma e i^{2}}\left(E R B i-C^{*}\right)
$$

Keterangan:

$\mathrm{Wi}=$ Proporsi sekuritas ke $\mathrm{i}$

$\mathrm{Zi} \quad=$ Skala tertimbang

$\mathrm{K}=$ Jumlah sekuritas di portofolio optimal 


$$
\begin{array}{ll}
\beta \mathrm{i} & =\text { Beta sekuritas ke-i } \\
\sigma_{\mathrm{ei}}{ }^{2} & =\text { Varian dari kesalahan residu sekuritas ke-i } \\
\mathrm{ERBi} & =\text { Excess return to beta sekuritas ke-i } \\
\mathrm{C}^{*} & =\text { Nilai cut-off point yang merupakan nilai Ci terbesar }
\end{array}
$$

2 Menghitung return portofolio.

Return Ekspektasi Portofolio dihitung dengan rumus sebagai berikut:

$\mathrm{E}(\mathrm{Rp})=\sum_{i=1}^{n}[\mathrm{Wi} . \mathrm{E}(\mathrm{Ri})]$

Keterangan:

$\mathrm{E}(\mathrm{Rp}) \quad=$ return ekspektasi portofolio

$\mathrm{Wi}_{\mathrm{i}} \quad=$ porsi dari sekuritas i terhadap seluruh sekuritas di portofolio

$\mathrm{E}\left(\mathrm{R}_{\mathrm{i}}\right) \quad=$ return ekspektasi dari sekuritas ke-i

$\mathrm{n} \quad=$ jumlah dari sekuritas tunggal

3 Menghitung Risiko Portofolio

Risiko portofolio adalah varian return sekuritas-sekuritas yang membentuk portofolio tersebut. Tingkat risiko dari suatu portofolio saham yang dinyatakan dalam bentuk varian portofolio dapat ditentukan dengan persamaan berikut:

$\sigma \mathrm{p}^{2}=\left(\sum_{i=1}^{n} \mathrm{wi} \cdot \beta \mathrm{i}\right)^{2} \sigma \mathrm{m}^{2}+\left(\sum_{i=1}^{n} \mathrm{wi} \cdot \sigma \mathrm{ei}\right)$

4 Menganalisis risiko portofolio menggunakan perhitungan Value at Risk metode simulasi Monte Carlo dengan bantuan program Risk Analysis Simulator (copyright dari UNPAD) yaitu berupa fitur tambahan pada Microsoft Excel untuk menganalisis suatu risiko dengan langkah pengerjaan sebagai berikut:

a. Menginput data risiko portofolio yang telah dihitung menggunakan metode Single Index Model.

b. Menentukan asumsi (define assumption), dimana sebelum melakukan simulasi, terlebih dahulu menentukan asumsi distribusi dari populasi data yang diharapkan.

c. Menentukan perkiraan (define forecast), yaitu melakukan perkiraan percobaan berulang kali sebanyak 1000 kali.

d. Jalankan simulator (run simulator), artinya data yang telah dimasukan akan melakukan running atau iterasi sebanyak percobaan yang telah ditentukan yaitu sebanyak 1000 kali, maka akan dihasilkan 1000 angka acak mengikuti pola distribusi yang dipilih.

e. Menganalisis keluaran simulasi sehingga Value at Risk (VaR) suatu portofolio dapat dihitung dengan rumus: $\mathrm{VaR}=$ Mean $-\mathrm{Z}$ score. (Standar Deviasi)

\section{Hasil Penelitian}

\section{HASIL PENELITIAN}

\section{Portofolio Optimal Dengan Metode Single Index Model}

Pembentukan portofolio optimal menggunakan metode Single Index Model (Model Indeks Tunggal) yaitu berdasarkan besarnya nilai ERB dan cut-off point. Saham yang masuk dalam portofolio optimal adalah saham yang mempunyai nilai excess return to beta lebih besar atau sama dengan nilai cut- of-point. Nilai cut-off point $\left(\mathrm{C}^{*}\right)$ adalah nilai $\mathrm{Ci}$ tertinggi dari seluruh nilai $\mathrm{Ci}$ saham. Berikut tabel kalkulasi pembentukan portofolio optimal periode 2015-2018: 
Tabel 2. Kalkulasi pembentukan portofolio optimal periode 2015-2018

\begin{tabular}{|c|c|}
\hline Semester & Saham Yang Membentuk Portofolio \\
\hline 1 & $\begin{array}{l}\text { 1) GGRM (Gudang Garam Tbk) } \\
\text { 2) BMTR (Global Mediacom Tbk) } \\
\text { 3) SILO (Siloam International Hospital Tbk) } \\
\text { 4) ASRI (Alam Sutera Realty Tbk) }\end{array}$ \\
\hline 2 & ITMG (Indo Tambangraya Megah Tbk) \\
\hline 3 & $\begin{array}{l}\text { 1) JSMR (Jasa Marga (Persero) Tbk) } \\
\text { 2) GGRM (Gudang Garam Tbk) } \\
\text { 3) SCMA (Surya Citra Media Tbk) } \\
\text { 4) TBIG (Tower Bersama Infrastructure Tbk) }\end{array}$ \\
\hline 4 & $\begin{array}{l}\text { 1) INTP (Indocement Tunggal Prakasa Tbk) } \\
\text { 2) MPPA (Matahari Putra Prima Tbk) } \\
\text { 3) WIKA (Wijaya Karya (Persero) Tbk) } \\
\text { 4) PGAS (Perusahaan Gas Negara (Persero) Tbk) } \\
\text { 5) PWON (Pakuwon Jati Tbk) } \\
\text { 6) PTPP (PT Pembangunan Perumahan Tbk) } \\
\text { 7) } \\
\text { AALI (Astra Agro Lestari Tbk) }\end{array}$ \\
\hline 5 & $\begin{array}{l}\text { 1) ELSA (Elnusa Tbk) } \\
\text { 2) LPKR (Lippo Karawaci Tbk) } \\
\text { 3) PPRO (PT Pembangunan Perumahan Properti Tbk) } \\
\text { 4) AALI (Astra Agro Lestari Tbk) } \\
\text { 5) PTPP (PT Pembangunan Perumahan Tbk) } \\
\text { 6) ASRI (Alam Sutera Realty Tbk) } \\
\text { 7) ADRO (Adaro Energy Tbk) } \\
\text { 8) AKRA (AKR Corporindo Tbk) } \\
\text { 9) ANTM (Aneka Tambang (Persero) Tbk) }\end{array}$ \\
\hline 6 & $\begin{array}{l}\text { 1) SSMS (Sawit Sumbermas Sarana Tbk) } \\
\text { 2) AALI (Astra Agro Lestari Tbk) }\end{array}$ \\
\hline 7 & 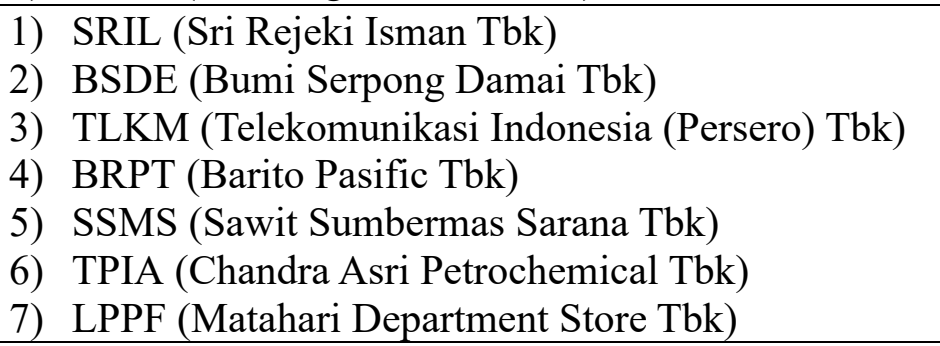 \\
\hline 8 & $\begin{array}{l}\text { 1) SMRA (Summarecon Agung Tbk) } \\
\text { 2) } \text { ANTM (Aneka Tambang (Persero) Tbk) } \\
\text { 3) PTPP (PT Pembangunan Perumahan Tbk) } \\
\text { 4) TLKM (Telekomunikasi Indonesia (Persero) Tbk) } \\
\text { 5) SMGR (Semen Indonesia (Persero) Tbk) } \\
\text { 6) } \\
\text { SRIL (Sri Rejeki Isman Tbk) }\end{array}$ \\
\hline
\end{tabular}

Tabel diatas menunjukkan bahwa saham-saham yang masuk dalam portofolio tiap semester terlihat berbeda-beda. Saham yang masuk dalam portofolio optimal dari periode 2015 sampai 2018 diantaranya: GGRM, BMTR, SILO, ASRI, ITMG, JSMR, SCMA, TBIG, INTP, MPPA, WIKA, PGAS, PWON, PTPP, AALI, ELSA, LPKR, PPRO, ADRO, AKRA, ANTM, SSMS, SRIL, BSDE, TLKM, BRPT, TPIA, LPPF, 
SMRA, ANTM, SMGR, dan SRIL.

Berdasarkan hasil perhitungan yang telah dilakukan dengan menggunakan Microsoft Excel diperoleh hasil return dan risiko portofolio optimal dengan menggunakan Single Index Model pada saham indeks LQ45 periode 2015-2018 yang terbagi menjadi 8 semester.

Tabel 3. Expected Return Portofolio dan Risiko Portofolio Saham LQ45

\begin{tabular}{|l|c|c|}
\hline & E (Rp) & op \\
\hline Semester 1 & $-0,045232$ & 0,091512 \\
Semester 2 & $-0,120167$ & 0,126121 \\
Semester 3 & $-0,024191$ & 0,036166 \\
Semester 4 & $-0,029817$ & 0,051941 \\
Semester 5 & $-0,028491$ & 0,032905 \\
Semester 6 & $-0,003493$ & 0,016772 \\
Semester 7 & $-0,024299$ & 0,047899 \\
Semester 8 & $-0,0047$ & 0,052727 \\
\hline
\end{tabular}

Sumber: Data diolah, Microsoft Excel

Berdasarkan tabel diatas dapat dilihat bahwa nilai return maupun risiko antara pembentukan portofolio optimal dengan Single Index Model menunjukkan bahwa besarnya risiko portofolio menggambarkan besar risiko yang tertanggung oleh investor atas tingkat imbal hasil tertentu.

\section{Risiko Portofolio Menggunakan Perhitungan Value at Risk Metode Simulasi Monte Carlo}

Menganalisis risiko portofolio menggunakan perhitungan Value at Risk metode simulasi Monte Carlo dapat dilakukan dengan bantuan program Risk Analysis Simulator yaitu berupa fitur tambahan pada Microsoft Excel. Berikut hasil simulasi menggunakan Risk Analysis Simulator.

\begin{tabular}{|l|r|}
\hline \multicolumn{1}{|c|}{ Statistics } & \multicolumn{2}{c|}{ Value } \\
\hline Trials & 1.000 \\
\hline Mean & 0,05242 \\
\hline Median & 0,050000001 \\
\hline Mode & 0,050000001 \\
\hline Standard Deviation & 0,004285085 \\
\hline Variance & $1,8362 \mathrm{E}-05$ \\
\hline Skewness & 1,207 \\
\hline Kurtosis & 2,455 \\
\hline Coeff. Variation & 0,082 \\
\hline Mean Std. Error & 0,000135506 \\
\hline Range Minimum & 0,050000001 \\
\hline Range Maximum & 0,059999999 \\
\hline Range Width & 0,009999998 \\
\hline Time & $51.17 \mathrm{~s}$ \\
\hline
\end{tabular}

Berdasarkan hasil simulasi diatas, Value at Risk (VaR) suatu portofolio dapat dihitung dengan rumus:

$$
\mathrm{VaR}=\text { Mean }-\mathrm{Z} \text { statistik } / Z \text { score. }(\text { Standar Deviasi) }
$$




$$
\begin{aligned}
& =0,05242-1,65 \cdot(0,004285085) \\
& =0,04534961
\end{aligned}
$$

Jika investasi awal sebesar 1 milyar, maka:

$=0,04534961 \times 1.000 .000 .000$

$=\operatorname{Rp} 45.349 .610$

Dalam penelitian ini menggunakan $5 \%$ dalam membatasi untuk menerima risiko, sehingga tabel $\mathrm{Z}$ menunjukkan nilai 1,65.

\section{PEMBAHASAN}

\section{Analisis Pembentukan Portofolio Optimal Saham}

Berdasarkan hasil analisis penelitian perkembangan 61 saham selama periode 2015 sampai 2018 yang terbagi menjadi 8 semester, adalah sebagai berikut:

\section{a. Semester pertama: Februari - Juli 2015}

Pembentukan portofolio optimal berdasarkan Single Index Model dengan menggunakan program Microsoft Excel pada saham LQ45 periode Februari 2015 sampai Juli 2015 terdapat 4 saham yang masuk dalam portofolio optimal yaitu GGRM, BMTR, SILO, dan ASRI. Besarnya proporsi dana yang dapat diinvestasikan pada empat saham tersebut adalah:

1) GGRM sebesar 0,3158 atau $31,58 \%$

2) BMTR sebesar 0,3044 atau $30,44 \%$

3) SILO sebesar 0,0445 atau $4,45 \%$

4) ASRI sebesar 0,3351 atau $33,51 \%$

Dari proporsi tersebut return portofolio yang dihasilkan sebesar -0,04523 atau $4,52 \%$ dan risiko portofolio sebesar 0,09151 atau $9,15 \%$.

b. Semester dua: Agustus 2015 - Januari 2016

Pembentukan portofolio optimal berdasarkan Single Index Model dengan menggunakan program Microsoft Excel pada saham LQ45 periode Agustus 2015 sampai Januari 2016 hanya membentuk 1 saham yang masuk dalam portofolio optimal yaitu ITMG dengan besarnya proporsi dana yang dapat diinvestasikan pada aham tersebut adalah $100 \%$. Dari proporsi tersebut return portofolio yang dihasilkan sebesar $-0,12016$ atau $-12,02 \%$ dan risiko portofolio sebesar 0,12612 atau $12,61 \%$.

c. Semester tiga: Februari - Juli 2016

Pembentukan portofolio optimal berdasarkan Single Index Model dengan menggunakan program Microsoft Excel pada saham LQ45 periode Februari 2016 sampai Juli 2016 terdapat 4 saham yang masuk dalam portofolio optimal yaitu JSMR, GGRM, SCMA, dan TBIG. Besarnya proporsi dana yang dapat diinvestasikan pada empat saham tersebut adalah:

1) JSMR sebesar 0,61136 atau $61,14 \%$

2) GGRM sebesar 0,22136 atau $22,14 \%$

3) SCMA sebesar 0,10608 atau 10,61\%

4) TBIG sebesar 0,06118 atau $6,12 \%$

Dari proporsi tersebut return portofolio yang dihasilkan sebesar $-0,02419$ atau $2,42 \%$ dan risiko portofolio sebesar 0,03616 atau 3,62 \%.

d. Semester empat: Agustus 2016 - Januari 2017

Pembentukan portofolio optimal berdasarkan Single Index Model dengan menggunakan program Microsoft Excel pada saham LQ45 periode Agustus 2016 sampai Januari 2017 terdapat 7 saham yang masuk dalam portofolio optimal yaitu 
INTP, MPPA, WIKA, PGAS, PWON, PTPP dan AALI. Besarnya proporsi dana yang dapat diinvestasikan pada empat saham tersebut adalah:
1) INTP sebesar 0,2360 atau $23,60 \%$
2) MPPA sebesar 0,0849 atau $8,49 \%$
3) WIKA sebesar 0,0324 atau $3,24 \%$
4) PGAS sebesar 0,0350 atau $3,50 \%$
5) PWON sebesar 0,0118 atau $1,18 \%$
6) PTPP sebesar 0,5466 atau 54,66\%
7) AALI sebesar 0,0530 atau 5,30\%

Dari proporsi tersebut return portofolio yang dihasilkan sebesar -0,02981 atau $2,98 \%$ dan risiko portofolio sebesar 0,05194 atau 5,19\%.

e. Semester lima: Februari - Juli 2017

Pembentukan portofolio optimal berdasarkan Single Index Model dengan menggunakan program Microsoft Excel pada saham LQ45 periode Februari 2017 sampai Juli 2017 terdapat 9 saham yang masuk dalam portofolio optimal yaitu ELSA, LPKR, PPRO, AALI, PTPP, ASRI, ADRO, AKRA dan ANTM. Besarnya proporsi dana yang dapat diinvestasikan pada empat saham tersebut adalah:

1) ELSA sebesar 0,0494 atau $4,94 \%$

2) LPKR sebesar 0,0092 atau $0,92 \%$

3) PPRO sebesar 0,0929 atau $9,29 \%$

4) AALI sebesar 0,2467 atau $24,67 \%$

5) PTPP sebesar 0,3207 atau 32,07\%

6) ASRI sebesar 0,2480 atau 24,80\%

7) ADRO sebesar 0,0050 atau $0,50 \%$

8) AKRA sebesar 0,0156 atau $1,56 \%$

9) ANTM sebesar 0,0120 atau $1,20 \%$

Dari proporsi tersebut return portofolio yang dihasilkan sebesar -0,02849 atau $2,85 \%$ dan risiko portofolio sebesar 0,03291 atau 3,29\%.

f. Semester enam: Agustus 2017 - Januari 2018

Pembentukan portofolio optimal berdasarkan Single Index Model dengan menggunakan program Microsoft Excel pada saham LQ45 periode Agustus 2017 sampai Januari 2018 terdapat 2 saham yang masuk dalam portofolio optimal yaitu SSMS dan AALI. Besarnya proporsi dana yang dapat diinvestasikan pada dua saham tersebut adalah SSMS sebesar 0,9056 atau 90,56 \% dan AALI sebesar 0,0943 atau $9,43 \%$. Dari proporsi tersebut return portofolio yang dihasilkan sebesar 0,00349 atau $-0,35 \%$ dan risiko portofolio sebesar 0,01677 atau $1,68 \%$.

g. Semester tujuh: Februari - Juli 2018

Pembentukan portofolio optimal berdasarkan Single Index Model dengan menggunakan program Microsoft Excel pada saham LQ45 periode Februari 2018 sampai Juli 2018 terdapat 7 saham yang masuk dalam portofolio optimal yaitu SRIL, BSDE, TLKM, BRPT, SSMS, TPIA, dan LPPF. Besarnya proporsi dana yang dapat diinvestasikan pada empat saham tersebut adalah:
1) SRIL sebesar 0,3118 atau $31,18 \%$
2) BSDE sebesar 0,0467 atau $4,67 \%$
3) TLKM sebesar 0,0121 atau $1,21 \%$
4) BRPT sebesar 0,0197 atau 1,97\%
5) SSMS sebesar 0,0279 atau $2,79 \%$
6) TPIA sebesar 0,3798 atau $37,98 \%$
7) LPPF sebesar 0,2016 atau $20,16 \%$ 
Dari proporsi tersebut return portofolio yang dihasilkan sebesar -0,02429 atau $2,43 \%$ dan risiko portofolio sebesar 0,0479 atau $4,79 \%$.

h. Semester delapan: Agustus 2018 - Januari 2019

Pembentukan portofolio optimal berdasarkan Single Index Model dengan menggunakan program Microsoft Excel pada saham LQ45 periode Agustus 2018 sampai Januari 2019 terdapat 6 saham yang masuk dalam portofolio optimal yaitu SMRA, ANTM, PTPP, TLKM, SMGR, dan SRIL. Besarnya proporsi dana yang dapat diinvestasikan pada empat saham tersebut adalah:

1) SMRA sebesar 0,15291 atau $15,29 \%$

2) ANTM sebesar 0,03283 atau $3,28 \%$

3) PTPP sebesar 0,04736 atau $4,74 \%$

4) TLKM sebesar 0,08408 atau $8,41 \%$

5) SMGR sebesar 0,59956 atau $59,96 \%$

6) SRIL sebesar 0,08322 atau $8,32 \%$

Dari proporsi tersebut return portofolio yang dihasilkan sebesar -0,0047 atau $0,47 \%$ dan risiko portofolio sebesar 0,05272 atau $5,27 \%$.

\section{Analisis Risiko Portofolio Menggunakan Perhitungan Value at Risk Metode Simulasi Monte Carlo}

Value at Risk (VaR) secara sederhana dapat didefinisikan sebagai estimasi maksimal kerugian potensial dalam kondisi pasar yang normal pada periode waktu tertentu dan dengan tingkat kepercayaan tertentu. Untuk perhitungannya dapat dilakukan dengan metode Simulasi Monte Carlo. Adapun penggunaan metode ini didasarkan pada pembangkitan bilangan random. Dengan menggunakan program Microsoft Excel dan tambahan aplikasi Risk Analysis Simulator untuk menghitung risiko portofolio pada saham-saham yang terdaftar pada indeks LQ45 di Bursa Efek Indonesia periode 2015 sampai 2018 menghasilkan nilai VaR sebesar 0,04534961. Artinya jika dana awal yang diinvestasikan pada portofolio saham LQ45 sebesar 1.000.000.000,00, maka pada tingkat kepercayaan 95\% dengan seribu kali ulangan (trial), menghasilkan rata- rata nilai $\operatorname{VaR} 0,04534961$ (menunjukkan kerugian). Hal ini dapat diartikan ada keyakinan sebesar 95\% bahwa kerugian yang mungkin akan diderita investor tidak akan melebihi Rp 45.349.610 atau dengan kata lain dapat dikatakan ada kemungkinan sebesar 5\% bahwa kerugian investasi pada portofolio saham LQ45 dapat diterima.

\section{Kesimpulan}

\section{KESIMPULAN DAN SARAN}

Berdasarkan pembahasan mengenai pengukuruan Value at Risk (VaR) portofolio saham indeks LQ45 dengan menggunakan metode Simulasi Monte Carlo yang telah diuraikan maka dapat diambil kesimpulan yaitu:

a. Penerapan analisis risiko portofolio dengan metode Simulasi Monte Carlo yang dibahas dalam penelitian ini adalah pada saham-saham yang terdaftar di indeks LQ45 periode 2015 sampai 2018.

b. Pembentukan portofolio optimal dengan menggunakan model indeks tunggal mampu menghasilkan portofolio optimal pada saham-saham indeks LQ45 periode Februari 2015 sampai Januari 2018 dengan pertimbangan nilai ERB lebih besar dari nilai cut off point. Nilai VaR portofolio saham LQ45 periode 2015-2018 sebesar 0,04534961 yang berarti menunjukkan kerugian yang akan diderita oleh investor tidak akan melebihi Rp 45.349.610. 


\section{Saran}

Berdasarkan hasil penelitian, saran-saran yang dapat diberikan adalah:

1. Bagi perusahaan yang sahamnya belum masuk dalam pembentukan portofolio optimal diharapkan dapat melakukan evaluasi kinerja saham. Evaluasi ini dapat bertujuan untuk mendapatkan return yang optimal sehingga dapat dijadikan investasi oleh investor dimasa mendatang.

2. Bagi investor dan calon investor dapat menginvestasikan dananya pada saham GGRM, BMTR, SILO, ASRI, ITMG, JSMR, SCMA, TBIG, INTP, MPPA, WIKA, PGAS, PWON, PTPP, AALI, ELSA, LPKR, PPRO, ADRO, AKRA, ANTM, SSMS, SRIL, BSDE, TLKM, BRPT, TPIA, LPPF, SMRA, ANTM, SMGR, dan SRIL sebagai alternatuf pilihan karena saham-saham tersebut merupakan saham perusahaan yang masuk dalam portofolio optimal dari periode 2015 sampai 2018.

3. Bagi peneliti selanjutnya diharapkan dapat melanjutkan pembahasan mengenai analisis risiko portofolio dengan metode yang lain seperti simulasi historis dan metode varians kovarians. Disamping itu dapat memperluas pembahasan mengenai analisis risiko portofolio pada investasi keuangan yang lain seperti obligasi dan lainlain.

\section{REFERENSI}

Devi, Silvia Sinta. 2010. Analisis Risiko Portofolio dengan Metode Varians Kovarians. Yogyakarta: Universitas Negeri Yogyakarta.

Halim, Abdul. 2005. Analisis Investasi. Edisi kadua. Jakarta: Salemba Empat.

Hartono, Jogiyanto. 2014. Teori dan Praktik Portofolio Dengan Excel. Jakarta: Salemba Empat Yogyakarta: BPFE.

2016. Portofolio dan Analisis Investasi. Edisi Kesepuluh.

Husnan, Suad. 2015. Dasar-Dasar Teori Portofolio dan Analisis Sekuritas. Yogyakarta: UPP STIM YKPN

Indarto, Roni. 2014. Teori Portofolio dan Analisis Investasi. Edisi Pertama. Tangerang Selatan: Universitas Terbuka.

Jorion, Philippe. 2007. Value at Risk: The New Benchmark Managing Financial Risk. Third Edition. New York: The Mc Graw-Hill Companies.

Martono, Nanang. 2016. Metode Penelitian Kuantitatif. Jakarta: PT Raya Grafindo Persada.

Mohamad, Samsul. 2006. Pasar Modal dan Manajemen Portofolio. Jakarta: Erlangga.

Ningsih, Ryke Turya. 2014. Analisis Risiko Portofolio dengan Menggunakan Metode Simulasi Monte Carlo. Yogyakarta, UIN Sunan Kalijaga: Fakultas Sains dan Teknologi.

Qadafhi, Achmad. 2012. Penggunaan Metode Simulasi Monte Carlo Dalam Mencari Value at Risk (Var) Pada Portofolio. Medan, Universitas Sumatera Utara: Fakultas Matematika Dan Ilmu Pengetahuan Alam. 
Rohmaniah, Siti Alfiatur. 2016. Perhitungan Value at Risk (VaR) dengan Simulasi Monte Carlo (Studi Kasus Saham Pt. Xl Aciata. Tbk). Jurnal UJMC, Volume 3, Nomor 1, Hal. 15 - 20 p-ISSN: 2460-3333 e-ISSN: 2579-907X.

Sofiana, Nita. 2011. Pengukuran Value at Risk Pada Portofolio dengan Simulasi Monte Carlo. Yogyakarta: Universitas Negeri Yogyakarta.

Sugiyono. 2017. Metode Penelitian Kuantitatif, Kualitatif, dan R\&D. Bandung: Alfabeta.

Sunariyah. 2003. Pengantar Pengetahuan Pasar Modal. Edisi Ketiga. Yogyakarta: UPP AMPK YKPN.

Susilo, Bambang. 2009. Pasar Modal Mekanisme Perdagangan Saham, Analisis Sekuritas, dan strategi Investasi Di Bursa Efek Indonesia (BEI). Yogyakarta: $U P P$.

Tandelilin, Eduardus. 2001. Analisis Investasi Dan Manajemen Portofolio. Edisi Pertama. Yogyakarta: BPFE Yogjakarta.

Warsono. 2001. Analisis Investasi dan Manajemen Portofolio. Malang. UMM PRESS

Website: www.bi.go.id diakses pada 15 Februari 2019

Website: www.idx.co.id diakses pada tanggal 15 Februari 2019

Website: www. yahoofinance.com_diakses pada tanggal 15 Februari 2019

Website: www.sahamok.com diakses pada tanggal 15 Februari 2019 